DOI https://doi.org/10.18551/rjoas.2017-06.43

\title{
RESPONSE OF RED CHILLI VARIETIES UNDER DROUGHT STRESS
}

\author{
Budiyati Ichwan* \\ Agroecotechnology Department, Faculty of Agriculture, University of Jambi, Indonesia
}

Rujito A. Suwignyo, Renih Hayati, Susilawati

Agronomy Department, Faculty of Agriculture, University of Sriwijaya, Indonesia

*E-mail: budiyati ichwan@yahoo.com

\begin{abstract}
Red chilli (Capsicum annuum L.) is the vegetable commodity that is widely cultivated in Indonesia. Growth and yields of the plants may be hampered by drought stress. The research to evaluate the effect of drought stress to agronomical and physiological characteristics of red chilli was done from October 2015 to April 2016 in a screen house of the Horticulture Seed Centre, Jambi Province, Indonesia. The Split Plot Design was used in this research with drought stress as main plot $(100 \%, 75 \%, 50 \%$ of field capacity, FC) and chilli varieties as sub plot (Lado, Kastilo, BCA, Tanamo, Laris, Romario, Ferosa, Azimuth). The maximum decrease of growth and yield was recorded under the high level of water stress $(50 \%$ FC) compared to optimum water supply (100\% FC). The tolerance chilli varieties will increase the proline content and maintain the total sugar and chlorophyll content. Tanamo, Lado, Kastilo and BCA are varieties that can survive under drought stress and still provide the higher yield.
\end{abstract}

\section{KEY WORDS}

Agronomy, physiology, drought, red chilli, Capsicum annuum.

Red chilli (Capsicum annuum L.) is one of the commodities of vegetables that have an important meaning because it has economic value and high nutrient content in Indonesia. In Indonesia, red chilli production in 2015 is 1.045 .182 ton, and its productivity is 8.65 ton per hectare (Ministry of Agriculture, 2016). Global warming and climate change that is occurring today cause the limited water availability for crops, this is an obstacle in efforts to increase production and productivity of red chilli (Budiastuti, 2010).

The inadequacy of availability of water will cause drought stress to plants. Drought stress is one of the factors that can impede seriously cultivated area production and it is also considered as a severe threat for sustainable crop production in conditions of climate change (Anjuum et al., 2011; Hammad and Ali, 2014).

The plant will respond to the drought by changing its morphological and physiological characteristics. The growth of plant shoot, crop growth rate, number and leaf area, plant fresh and dry weight are decreased caused by drought (Abdalla, 2014). The increasing of proline concentration to the plants is a mutation of plant physiological characteristics that experiences drought stress (Djazuli, 2010).

The intensity of drought, the length of drought, species and the genotype of plants are the factors can be affected yields losses from drought (Demirevska et al., 2009). Decreasing water availability to $40 \%$ filed capacity for three months reducing fresh weight and dry weight of purwoceng (Pimpinella pruatjan Molk.).

The improvement of plant characteristics related to adaptation to the environment experiencing water stress or use of crop varieties that are tolerant to drought stress is an effort that can be done to reduce losses from drought (Abdul Malik, 2012; Sumartini, et al., 2013).

The assessment of the character changes in agronomy and physiology in the various varieties of red chilli in different levels of drought stress needs to be done to get red chilli varieties that are tolerance to drought stress. This research was aimed to evaluate the 
agronomical and physiological changes that occur on different varieties of red chilli in different levels of drought stress.

\section{MATERIALS AND METHODS OF RESEARCH}

The research was conducted in a screen house of the Horticulture Seed Center, Sungai Tiga, Jambi (101 10'-104 55'BT - $045^{\prime}-245^{\prime}$ LS ) Indonesia, started from October 2015 until April 2016, using a Split Plot design in three replications. The main plot were three drought stress level (based on soil water content /field capacity, FC), i.e. 100\% FC; $75 \%$ FC and $50 \% \mathrm{FC}$. The determination of soil water content was calculated gravimetrically. The sub plot was red chilli varieties, i.e. Lado, Kastilo, BCA, Tanamo, Laris, Romario, Ferosa, and Azimuth. Selection of varieties based on popular varieties.

Drought stress is given from planting to harvest (0 Week After Planting / WAP to 15 WAP). Determination of soil water content using the gravimetric method with a formula:

$$
K a_{1}=100 \%(B t-B t K O N) / B t K O N
$$

The weight of soil + water in each treatment is as follows:

$$
\begin{gathered}
100 \% F C=\left(K a_{2} \times B t K O N\right)+B t K O N \\
75 \% F C=B t+\left[\left(75 \% \times K a_{2}\right)-K a_{1}\right] \times B t K O N \\
50 \% F C=B t+\left[\left(50 \% \times K a_{2}\right)-K a_{1}\right] \times B t K O N
\end{gathered}
$$

$\mathrm{Ka}_{1}$ is the first soil water content; $\mathrm{Ka}_{2}$ is water content at field capacity (100\% FC); $\mathrm{Bt}$ is soil weight/pot at the first soil water content and BtKON is soil dry weight.

The red chilli seeds were sown in seedling media and after the seedlings were 10 days old, they were transferred to the nursery until the age of 3 weeks, and then they were planted in $25 \times 40 \mathrm{~cm}$ of $10 \mathrm{~kg}$ soil of polybag. Media for the seedbed nursery and cultivation used was a mixture of soil, sand, and compost $(2: 1: 1)$. The plants were nourished by a standard method of red chilli care in a polybag.

The observation was done at the age of 4 and 8 weeks after planting (WAP) toward plant agronomy, i.e. a number of branches, shoot dry weight, root dry weight, fruit number, and fruit weight. Proline content, total sugar, and leaf chlorophyll at 8 WAP were physiology parameter observed. The method of Bates et al. (1973) was used to measure of proline content of fresh leaves. Total sugars were measured according to Irigoyen et al. (1992), and total chlorophyll was determined by immersion methods (Hall and Rao, 1987).

The data was analyzed using analysis of variance (ANOVA). Least Significant Different Test was used to see the difference of drought stress level, its varieties, and interaction, and the simple correlation of Pearson was also used to see the relationship between two pairs of parameters. Stress Susceptibility Index (SSI) is calculated using equation according to Fisher and Maurer (1978):

$$
S S I=(1-(Y s / Y p)) /\left(1-\left(Y_{S} /{ }^{\wedge} Y p\right)\right) ;
$$

$Y s$ and $Y p=$ observation value for one variety of drought stress and optimal conditions;

${ }^{\wedge} Y s$ and ${ }^{\wedge} Y p=$ observation value for all varieties of drought stress and optimal conditions.

\section{RESULTS AND DISCUSSION}

Effect of drought stress on plant agronomy. The result showed that the drought stress has not significantly different on parameters at 4 WAP but has significant different on branch number, shoot dry weight, fruit number, and fruit weight, except on root dry weight at 8 WAP. Drought stress at $75 \%$ FC decreased branch number of red chilli $26.37 \%$ ( $75 \%$ FC), and $58.93 \%$ (50\% FC) compared to 100\% FC. The highest decrease of branch number at $75 \%$ $\mathrm{FC}$ is Kastilo and the lowest is Ferosa, while BCA is the highest decrease and Ferosa is the lowest at $50 \%$ FC (Table 1). 
Table 1 - Reduction of branch number and shoot dry weight of red chilli varieties at drought stress levels

\begin{tabular}{|c|c|c|c|c|c|c|c|c|c|}
\hline \multirow{2}{*}{$\begin{array}{l}\text { Level of } \\
\text { drought }\end{array}$} & \multicolumn{8}{|c|}{ Reduction (\%) } & \multirow{2}{*}{$\begin{array}{c}\text { Average of } \\
\text { reduction } \\
(\%)\end{array}$} \\
\hline & Lado & Kastilo & $\mathrm{BCA}$ & Tanamo & Laris & Romario & Ferosa & Azimuth & \\
\hline \multicolumn{10}{|c|}{....branch number... } \\
\hline $75 \% \mathrm{FC}$ & 31.53 & 42.41 & 28.90 & 21.72 & 34.52 & 30.72 & 6.20 & 14.95 & 28.37 \\
\hline $50 \% \mathrm{FC}$ & 54.19 & 52.53 & 69.94 & 54.04 & 65.99 & 62.09 & 51.94 & 60.75 & 58.93 \\
\hline \multicolumn{10}{|c|}{...shoot dry weight... } \\
\hline $75 \% \mathrm{FC}$ & 25.96 & 26.16 & 32.04 & 29.60 & 20.75 & 11.42 & 10.32 & 26.48 & 22.84 \\
\hline $50 \%$ FC & 31.49 & 45.85 & 56.37 & 44.89 & 40.64 & 53.63 & 31.47 & 39.13 & 42.94 \\
\hline
\end{tabular}

The decline in the number of branches large enough from BCA at 50\% FC in line with the number of branches produced (17.33). Ferosa produces branch number is 20.67 (Fig. 1).

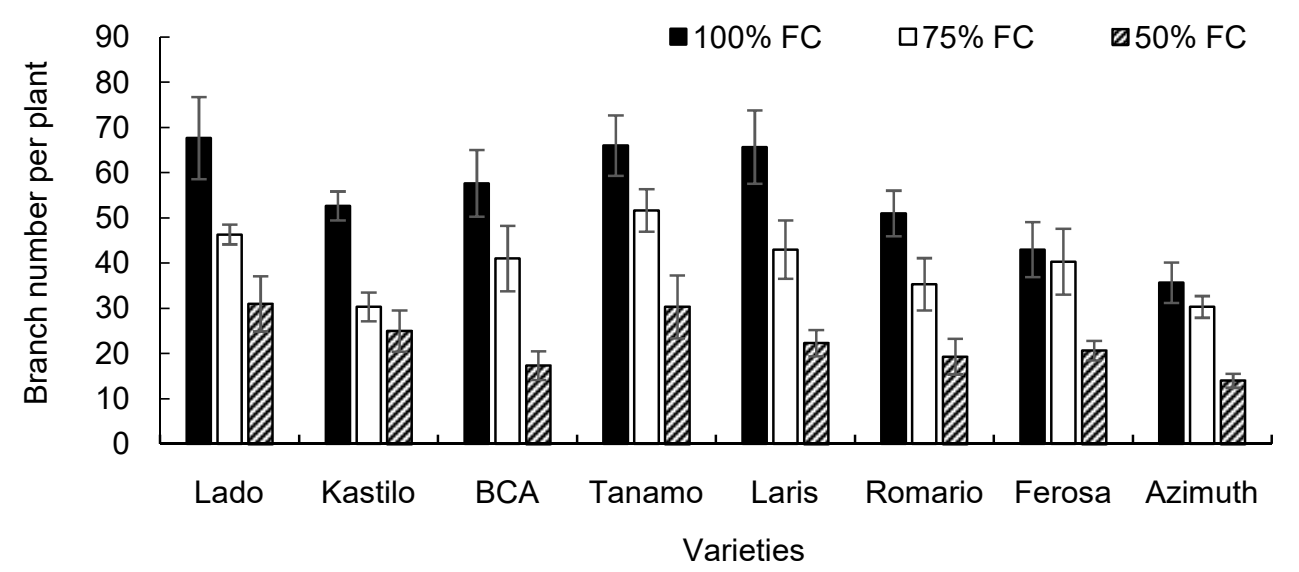

Figure 1 - Branch number of red chilli varieties at drought stress levels at 8 WAP. Error bars indicated standard error $(n=3)$

Increase drought stress lowered shoot dry weight at $75 \%$ FC (22.84\%) and $42.94 \%$ ( $50 \%$ FC). The biggest decrease of shoot dry weight of $50 \%$ FC is BCA and smallest is Ferosa (Table 1). Dry weight decreased of Kastilo at $75 \%$ FC and $50 \%$ FC is smaller than BCA. Tanamo gave a relatively similar response to Kastilo.

The dry weight of red chilli varieties at various levels of drought stress can be seen in Figure 2. The varieties of Kastilo and Tanamo have higher shoot dry weight (8.50 and 8.80) than BCA (7.62) at 50\% FC.

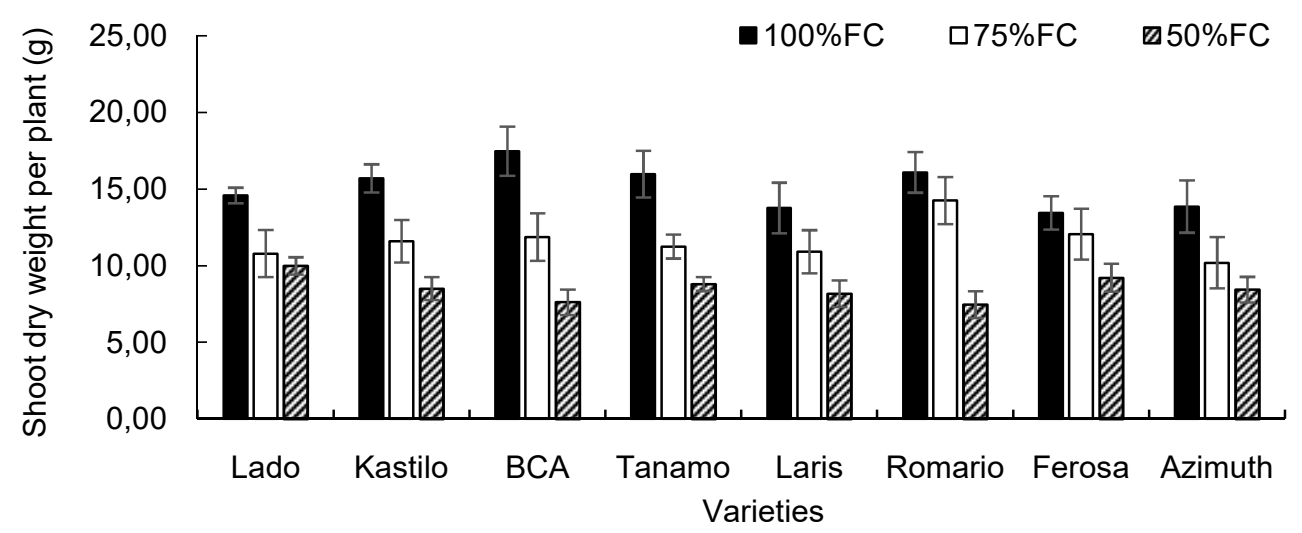

Figure 2 - Shoot dry weight of red chilli varieties at drought stress levels at 8 WAP. Error bars indicated standard error $(n=3)$ 
Reduced of water supply to plants or the transpiration rate increase caused drought stress (Anjuum et al., 2011). The plants will respond the shortage of water by lowering water content, decreasing the potential of water, leaf and cell turgor, closing the stomata, reducing the expansion and cell growth (Jaleel et al., 2002), that caused lowering growth and dry matter accumulation (Delfine et al., 2002). The result showed that drought stress condition will reduce the number of branches, followed by decreasing the shoot dry weight. The lowering of shoot dry weight was positively correlated with the number of branches of red chilli with $r=0.829(p<0.01)$ (Table 3$)$.

Root dry weight was not significantly affected by drought stress and varieties. Drought stress decreased root dry weight at $0.0005 \%$ (75\% FC) and $0.0018 \%(50 \%$ FC) (data not shown). The root length of peanuts did not effect by drought stress. The red chili tends to maintain the volume and root length at a certain depth to withstand drought stress (Riduan et al., 2005).

Drought stress decreased the number of fruit at $75 \%$ FC $(7.71 \%)$ and $29.50 \%(50 \%$ FC). The decline in the fruit number of Kastilo, BCA, and Tanamo was smaller than the others varieties (Table 2).

Table 2 - Reduction of fruit number and fruit weight of red chilli varieties at drought stress levels

\begin{tabular}{|c|c|c|c|c|c|c|c|c|}
\hline \multirow{2}{*}{ Level of drought } & \multicolumn{8}{|c|}{ Reduction (\%) } \\
\hline & Lado & Kastilo & $\mathrm{BCA}$ & Tanamo & Laris & Romario & Ferosa & Azimuth \\
\hline \multicolumn{9}{|c|}{....fruit number...... } \\
\hline $75 \% \mathrm{FC}$ & 5.00 & 4.95 & -1.25 & 5.08 & 4.55 & 20.55 & 3.08 & 19.75 \\
\hline $50 \% \mathrm{FC}$ & 37.50 & 16.83 & 18.75 & 19.49 & 31.82 & 36.99 & 27.69 & 46.91 \\
\hline \multicolumn{9}{|c|}{.....fruit weight ......... } \\
\hline $75 \% \mathrm{FC}$ & -2.23 & 6.52 & -2.63 & 5.66 & 6.12 & 24.22 & 10.48 & 18.32 \\
\hline $50 \%$ FC & 32.98 & 19.97 & 18.50 & 20.69 & 33.03 & 39.09 & 43.75 & 45.99 \\
\hline
\end{tabular}

The decrease in the number of fruits in the varieties of Kastilo, BCA and Tanamo produced more fruits than other varieties (Figure 3). The correlation analysis showed that the decrease in the number of fruit was more affected by the decrease in the number of branches compared with the decrease of shoot dry weight $(r=0.642, r=0.429, p<0.01)$ (Table 3).

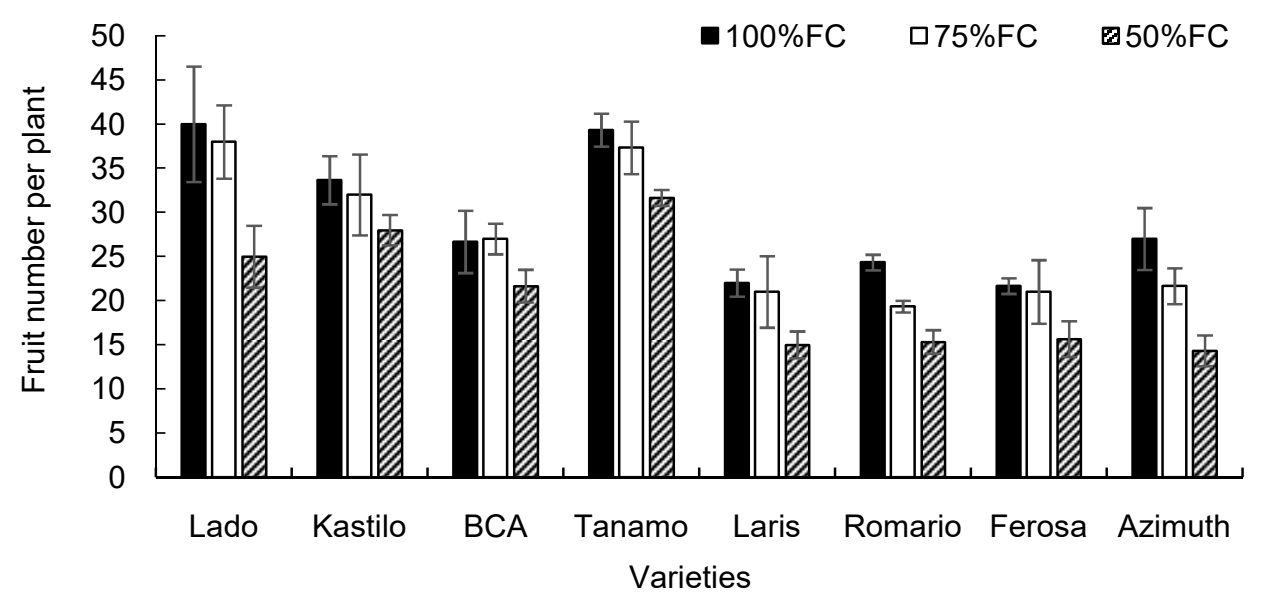

Figure 3 - Fruit number of red chilli varieties at drought stress levels. Error bars indicated standard error $(n=3)$

The branches number of red chilli greatly affects the number of flower buds produced because the flower buds on red chilli will appear on each branch (Poulos, 1994). Drought stress on some cultivars of sweet red chilli affects the number of flower buds, the percentage 
of flowers fall, the percentage of fruit set and fruit production (Abdulmalik et al., 2012). A decrease in the amount of tested fruit on the varieties of red chilli may also cause by the lowering of flower buds and increased flower fall percentage due to drought stress. The amount of fruit per plant on cultivar chilli "low and medium pungent" in drought stress is significantly lower than without drought stress (Phimcan et al., 2012).

The fruit weight of red chilli was decreased by drought stress at $8.31 \%(75 \% \mathrm{FC})$ and $31.75 \%$ (50\% FC) (Table 2). The decline of fruit number caused by the decrease of fruit number because of drought. Fruit weight is closely related to the number of branches and the number of fruits with $r$ respectively is 0.554 and 0.988 , but it was not significantly correlated to shoot dry weight $(r=0.348)$ (Table 3$)$.

Table 3 - The correlation coefficient between growth parameters at 8 WAP and yield at various of drought stress

\begin{tabular}{cccccc}
\hline Parameters & Branch number & Shoot dry weight & Root dry weight & Fruit number & Fruit weight \\
\hline Branch number & - & $0.829^{* *}$ & $0.430^{*}$ & $0.642^{* *}$ & $0.554^{* *}$ \\
Shoot dry weight & & - & $0.683^{* *}$ & $0.429^{*}$ & $0.307 \mathrm{tn}$ \\
Root dry weight & & & - & $0.195 \mathrm{tn}$ & $0.094 \mathrm{tn}$ \\
Fruit number & & & & - & $0.988^{* *}$ \\
\hline
\end{tabular}

Fruit number of red chilli varieties can be seen in Figure 4. Tanamo, Kastilo, and BCA have more fruit weight than the other varieties at $50 \%$ FC, except Lado.

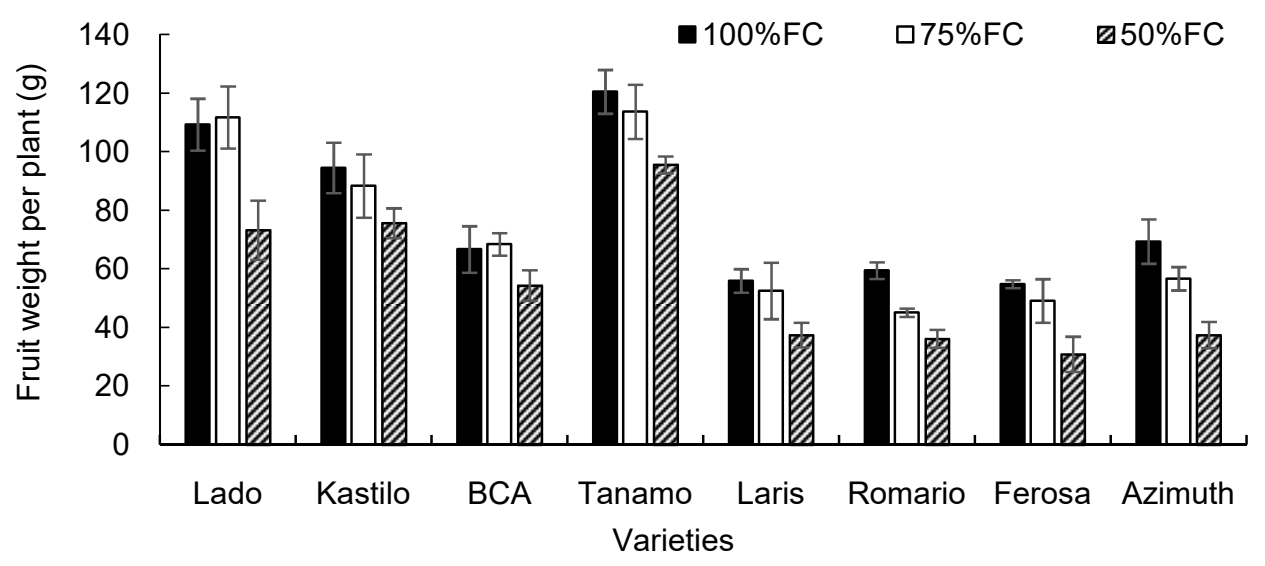

Figure 4 - Fruit weight of red chilli varieties at drought stress levels. Error bars indicated standard error $(n=3)$

The growth parameter that has a closer correlation to the number and weight of the fruit than other parameters is a number of branch. The decrease of branch number in drought stress $50 \% \mathrm{FC}$ is greater than $75 \% \mathrm{FC}$. Because of that, the number of branches at $50 \%$ FC can be used to filter the tolerance of red chilli to drought.

The plant susceptibility index to drought stress (SSI) calculated based on the number of branches, the number of fruits and the fruit weight at $50 \%$ drought of $\mathrm{KL}$ can be seen in Table 4.

Table 4 - SSI of eight red chilli varieties at $50 \%$ FC based on branch number at 8 WAP and plant yield

\begin{tabular}{|c|c|c|c|c|c|c|c|c|}
\hline \multirow{2}{*}{ Parameter } & \multicolumn{8}{|c|}{ SSI } \\
\hline & Lado & Kastilo & BCA & Tanamo & Laris & Romario & Ferosa & Azimuth \\
\hline Branch number & $0.92(\mathrm{~T})$ & $0.89(\mathrm{~T})$ & $1.18(\mathrm{P})$ & $0.92(\mathrm{~T})$ & $1.12(\mathrm{P})$ & $1.05(\mathrm{P})$ & $0.88(T)$ & $1.03(\mathrm{P})$ \\
\hline Fruit number & $1.29(\mathrm{P})$ & $0.58(\mathrm{~T})$ & $0.65(\mathrm{~T})$ & $0.67(\mathrm{~T})$ & $1.10(P)$ & $1.28(\mathrm{P})$ & $0.96(\mathrm{~T})$ & $1.62(\mathrm{P})$ \\
\hline Fruit weight & $1.11(P)$ & $0.67(\mathrm{~T})$ & $0.62(\mathrm{~T})$ & $0.70(\mathrm{~T})$ & $1.11(P)$ & $1.32(\mathrm{P})$ & $1.48(\mathrm{P})$ & $1.55(\mathrm{P})$ \\
\hline
\end{tabular}

The letters in parentheses indicate tolerance grouping into tolerant $(T)$ if $S S I<1.0$ and sensitive $(P)$ if $S S I \geq 1.0$ 
Based on SSI in Table 4, BCA, Kastilo, Tanamo and Ferosa are drought tolerant varieties, while Lado, Laris, Romario and Azimuth are sensitive. The drought tolerant varieties have fruit weight greater than the sensitive with smaller yield decreases except for Ferosa (Figure 4 and Table 2).

Effects of drought stress on plant physiology. The results showed that drought stress generally increases the levels of proline content at $4.79 \%$ (75\% FC) and $62.28 \%$ (50\% FC) (data not shown). Proline accumulation in plants is important in the effort to plant tolerance to osmotic stress (Shao, et al., 2005). Proline helps the plant reduce oxidative damage, and this is an important strategy for plants to withstand drought stress (Vendruscolo et al., 2007; Chegah, et al., 2013). Drought stress in various rice varieties increases the proline content (Maisura et al. 2014).

The proline content of BCA, Kastilo, Tanamo, and Ferosa increased with increasing drought (Table 5). The proline content of drought tolerant varieties is relatively higher compared to the sensitive varieties.

Table 5 - The content of proline, total sugar and red chilli chlorophyll at drought stress levels at 8 WAP

\begin{tabular}{|c|c|c|c|c|c|c|c|c|}
\hline \multirow{2}{*}{ Level of drought } & \multicolumn{8}{|c|}{ Varieties } \\
\hline & Lado & Kastilo & $\mathrm{BCA}$ & Tanamo & Laris & Romario & Ferosa & Azimuth \\
\hline \multicolumn{9}{|c|}{....prolin $(\mathrm{mM} / \mathrm{g}) \ldots \ldots$} \\
\hline $100 \% \mathrm{FC}$ & 0.26 & 0.20 & 0.19 & 0.25 & 0.20 & 0.15 & 0.13 & 0.29 \\
\hline $75 \%$ FC & 0.11 & 0.24 & 0.32 & 0.27 & 0.16 & 0.16 & 0.36 & 0.13 \\
\hline $50 \% \mathrm{FC}$ & 0.10 & 0.36 & 0.36 & 0.27 & 0.21 & 0.12 & 1.08 & 0.21 \\
\hline \multicolumn{9}{|c|}{....total sugar $(\mathrm{mg} / \mathrm{g}) \ldots$} \\
\hline $100 \% \mathrm{FC}$ & 42.17 & 45.47 & 41.79 & 50.00 & 32.92 & 35.28 & 36.04 & 46.51 \\
\hline $75 \% \mathrm{FC}$ & 27.14 & 27.27 & 21.69 & 33.77 & 49.16 & 25.65 & 39.87 & 37.6 \\
\hline $50 \% \mathrm{FC}$ & 11.36 & 20.91 & 20.82 & 23.55 & 18.36 & 20.45 & 38.27 & 28.91 \\
\hline \multicolumn{9}{|c|}{...total chlorophyll $\left(\mathrm{cm}^{2} / \mathrm{ml}\right) \ldots$} \\
\hline $100 \% \mathrm{FC}$ & 56.04 & 49.46 & 56.04 & 56.09 & 45.38 & 58.41 & 65.61 & 41.90 \\
\hline $75 \% \mathrm{FC}$ & 43.86 & 46.65 & 54.62 & 52.19 & 64.04 & 59.02 & 51.10 & 53.73 \\
\hline $50 \% \mathrm{FC}$ & 44.93 & 46.55 & 53.29 & 53.35 & 62.15 & 44.28 & 56.67 & 60.83 \\
\hline
\end{tabular}

Drought stress treatments lower total sugar content of almost all varieties of red chilli except Ferosa that has relatively constant (Table 5). Alfalfa total sugar content increase in mild drought, but with increasing drought stress, the total sugar content decreased compared with the plant under optimal conditions (Irigoyen et al., 1992). The decrease of total sugar content of Kastilo was higher compared with Tanamo $(52.90 \%)$ and BCA $(50.18 \%)$ at $50 \%$ FC (data not shown). Liu et al. (2011) found that intensive and prolonged drought would inhibit the accumulation of total sugar in two species of shrubs and four tree species.

Chlorophyll content of red chili varieties decreased with increasing drought. The decrease in chlorophyll content of drought tolerance red chilli varieties smaller than other varieties (Table 5). The sensitive varieties to drought stress have inability to chlorophyll synthesis (Sikuku et al. (2010).

The mechanism of red chilli tolerance to drought stress seems to be done by increasing the proline and maintaining its total sugar and chlorophyll content.

\section{CONCLUSION}

Sufficient water supply is fundamental to obtain optimal growth and yield of chilli. The decrease in the plant yield to drought stress was due to the reduced number of branches, shoot dry weight and number of fruits. Drought stress at $75 \%$ FC can already lower the agronomical and physiological characteristics of red chilli. Mechanism tolerance of red chilli to drought is done by increasing the proline content and maintaining its total sugar and chlorophyll content. Chilli varieties that able to withstand under drought stress and still provide higher yield was Tanamo, followed by Kastilo, Lado, and BCA. 


\section{ACKNOWLEGMENTS}

This work was supported by a Doctorate Research Competitive Fund, Directorate General of Higher Education, Ministry of Research, Technology and Higher Education, 2016. We express our gratitude for the assistance provided.

\section{REFERENCES}

1. Abdalla, M. M. 2014. Morphological and physiological changes in two Triticum aestivum differing in water stress tolerance. Journal of Agricultural Technology 10 (6): 1399 1420.

2. Abdulmalik, M. M., J. D. Obrewaju, I. S. Usman, and A. Ibrahim. 2012. Effects of moisture stress on flowering and fruit set in sweet pepper (Capsicum annuum L.) cultivars. Production Agriculture and Technology 8 (1): 191 - 198.

3. Anjuum, S. A., Xiao-yu Xie, Long-chang Wang, M. F. Saleem, C. Man and W. Lei. 2011. Morphological, physiological and biochemical responses of plants to drought stress (review). African Journal of Agricultural Research 6 (9): 2026 - 2032.

4. Bates, L. S., R. P. Waldren and I. D. Teare. 1973. Rapid determination of free proline for water stress studies. Plant and Soils 39: $205-207$.

5. Budiastuti, S. 2010. The phenomenon of climate change and continuity of agricultural production: a review of the empowerment of land resources. Journal Ekosains 2(1): 3339.

6. Chegah, S., M. Chehrazi, and M. Albaji. 2013. Effect of drought stress on growth and development Frankenia plant (Frankenia leavis). Bulg. J. Agr. Sci. 19: 659 - 665.

7. Delfine, S., R. Tognetti, F. Loreto and A. Alvino. 2002. Physiological and growth responses to water stress in field grown bell pepper (Capsicum annuum L.). Journal of Horticultural Science and Biotechnology 77 (6): 697 - 704.

8. Demirevska, D. Zasheva, R. Dimitrov, L. S. Stoilova, M. Stamenva and Urs Feller. 2009. Drougth stress effects on rubisco in wheat changes in the rubisco large subunit. Acta Physiol. Plant 31: $1129-1138$.

9. Djazuli, M. 2010. Effect of drought on growth and some morpho-physiological characters patchouli. Bull. Littro 21 (1): 8-17.

10. Fischer, R.A. and R. Maurer. 1978. Drought resistance in spring wheat cultivars: I. Grain yield responses. Aust. J. Agric. Res., 29: 897-912.

11. Hall, D. O. and K. K. Rao. 1987. Photosynthesis. 4thed. Kings Collage, University of London. London.

12. Hammad, S. A. R. and O. A. M. Ali. 2014. Physiological and biochemical studies on drought tolerance of wheat plants by application of amino acids and yeast extract. Annals of Agricultural Science 59 (1): 133 - 145.

13. Irigoyen, J.J., D.W. Einerich, and M. Sanchez-Diaz. 1992. Water stress induced changes in concentrations of proline and total soluble sugars innodulated alfalfa (Medicago sativa) plants. Physilogia plantarum 84:55-60.

14. Jaleel, C. A., P. Manivannan, A. Wahid, M. Farooq, H. J. A. Al-Juburi, R. Somasundaram and R. Pameerselvam. 2009. Drought stress in plant: A review on morphological characteristic and pigment composition. International Journal of Agriculture and Biology 11: $100-105$.

15. Liu C., Y. Liu, K. Guo, D. Fan, G. Li, Y. Zheng, L. Yu and R. Yang. Effect of drought on pigments, osmotic adjustment and antioxidant enzymes in six woody plant species in karst habitats of southwestern China. Environmental and Experiment Botany 71:174-183.

16. Maisura, M. A. Chozin, I. Lubis, A. Junaedi and H. Ehara. 2014. Some physiological character responses of rice under drought conditions in paddy system. J. ISSAAS 20 (1): 104-114.

17. Ministry of Agriculture. 2016. Area of harvest, production and productivity of red chilli in Indonesia. http//:www.pertanian.go.id/ap-pages/inod/hort-data (Accessed on 1 march 2017). 
18. Phimcan, P., S. Techawongstein, S. Chantai and P. W. Bosland. 2012. Impact of drought stress on the accumulation of capsaicinoids in capsicum cultivars with different initial capsaicinoid levels. HortScince 47 (9): $1204-1209$.

19. Poulos, J. M. 1994. Capsicum L., pp 136 - 140. In J. S. Siemonsma and K. Piluek (eds.). Plant Resources of South-East Asia 8. Vegetables. Bogor, Indonesia.

20. Riduan, A., H. Aswidinoor, J. Koswara and Sudarsono. 2005. Tolerance of several peanut cultivars against drought stress. Hayati: $28-34$.

21. Sumartini, S., E. Sulistyowati, S. Mulyani, and Abdurrahman. 2013. Screening strains of cotton (Gossypium hirsutum L.) tolerant to drought with PEG-6000 in phase of sprouts. Litri Journal 19 (3): 139-146.

22. Shao, H. B., Z.A. Liang and M.A. Shao. 2005. Changes of anti-oxidative enzymes and MDA content under soil water deficits among 10 wheat (Triticum aestivum L.) genotypes at maturation stages. Colloids Surf B.: Bionter. 45: $7-13$.

23. Sikuku, P. A., G. W. Netondo, J. C. Onyango and D. M. Musyimi. 2010. Chlorophyll fluorescence, protein and chlorophyll content of three nerica rainfed rice varieties under varying irrigation regimes. ARPN J. Agric. and Biol. Sci. 5: 19 -25.

24. Trisilawati, O. and J. Pitono. 2012. Effect of deficit water on active compound of purwoceng (Pimpinella pruatjan Molk). Bull. Litro 23 (1): $34-47$.

25. Vendruscolo, A.C.G., I. Schuster, M. Pileggi, C. A. Scapim, H.B.C. Molinari, C.J. Marur and L.G.C. Viera. 2007. Stress-induced synthesis of proline confers tolerance to water deficit in transgenic wheat. J. Plant Physiol. 164: 1367 - 1376. 